$\xi=1$

\title{
Qualimetric Approach in Determining the Investment Attractiveness of a Ukrainian Railway Entity
}

\author{
M.V.Bormotova ${ }^{1}$, S.D.Bronza ${ }^{1}$, T.V.Mashoshyna ${ }^{1}{ }^{*}$, O.M.Troinikova ${ }^{1}$ \\ ${ }^{1}$ Ukrainian State University of Railway Transport \\ *Corresponding author_E-mail:mashoshina_tatiana@ukr.net
}

\begin{abstract}
Investment is one of the critical tools to enable an economic recovery from the economic crisis and encourage the progressive development of any country. The main issue that prevents any industry from growing is shortage of funding. And that's exactly why assessment of investment attractiveness of any project (country, industry, region, or company) is highly important. Based on the study of the existing views on the definition of the concept of investment attractiveness in literary sources, these views have been grouped by the main essential feature used for the definitions.

The article presents an analysis of the investment attractiveness of Ukraine; articulates and systematizes the concept of investment attractiveness; suggests a definition of the concept in terms of qualimetry; examines the special aspects of investments in the transport industry (in particular, the railroad industry); and suggests a qualimetric model that enables the most adequate and essential assessment of the investment attractiveness of a railroad entity, based on the external and internal factors, and both qualitative and quantitative characteristics.
\end{abstract}

Keywords: investments; investment attractiveness; qualimetry;qualimetric mode;railroad industry.

\section{Introduction}

Investment is one of the critical tools to enable an economic recovery from the economic crisis and encourage the progressive development of any country. The main issue that prevents any industry from growing is shortage of funding. And therefore assessment of investment attractiveness of any project (country, industry, region, or company) is highly important.

The primary objective of qualimetry is a quantitative estimate of qualitative characteristics. Qualimetric methods allow to quantify the quality of totally different objects, which first can be expressed not only in numeric, but also in linguistic variables. One more task of qualimetry is defining (creation) of the qualitative characteristics, and expression of quantitative characteristics through the qualitative ones. For the purposes of this article, the qualimetric model of investment attractiveness of an entity is expressed as a mathematical model that allows to assess the investment attractiveness of an entity more accurately, taking into account the internal and external factors, both qualitative and quantitiave. One of the most important external factors is investment climate. One of the most important internal factors is financial position of an enterprise. Investment attractiveness plays a key role for investors when choosing a company to invest in.

The external factors of investment attractiveness can be divided into 3 groups (minimum)as follows: investment attractiveness of the country; investment attractiveness of the region; investment attractiveness of the industry, in which the entity operates; and other factors.

The internal factors of investment attractiveness can be divided into 6 groups (minimum) as follows:

- factors impacting financial position;

- production factors;

- management quality;
- factors to reflect the investment and innovation activity;

- factors impacting market stability;

- legal factors; and

- other factors.

Investment attractiveness of a country is assessed by a range of the following factors: social, political and economic stability; development of and the credit and financial system, legislative environment, level of corruption, quality of state regulation of economy; and situation on the stock market.

Investment attractiveness of a region is assessed by the level of economic and social development comparing to other regions of the country.

Investment attractiveness of the industry depends on the following factors: market capacity, level of competition, barriers to entry, price flexibility, capital intensity, resource availability, technological development level of the industry.

To sum up all the above, the factors that help to assess investment attractiveness (of a country, an industry, a region, or a company) form a multi-level system of the quantitative and qualitative characteristics to be taken into account. That is why a question of creating an adequate investment attractiveness assessment model arises. This model will allow to make a quantitative assessment of investment attractiveness with the help of a qualimetric approach.

\section{Literature Review}

\subsection{Investment Potential of Ukraine}

Due to its potential, vast labour resources and potentially large market capacity, Ukraine is a country with the very good opportunities for investments. The factors that form a favourable investment climate in Ukraine are as follows: 
- attractive and beneficial geographical position of Ukraine (Ukraine has an access to the strategic markets, in particular, to the EU, one the biggest world markets; and to the Middle East market);

- the largest European country with a high logistics potential;

- the biggest rail network density in Europe (22 million $\mathrm{km}$ of railways);

- natural resources potential (minerals, land and recreation are the most attractive areas for investment);

- level of industrial production development;

- highly-skilled and competitive labour force;

- goods market has not been shaped yet (Ukraine is potentially

one of the biggest market in Europe);

- consumer demand is not satisfied.

At the same time, a group of risks influence the investment attractiveness climate, and these risks are:

- war conflict in Eastern Ukraine;

- volatile political and economic situation;

- high rate of inflation;

- lack of detailed information about the investment opportunities;

- effective demand failure due to the lowest minimum and average wages among the European countries;

- market volatility, and hence foreign exchange rate fluctuations,

The World Economic Forum has published the Global Competitiveness Index for each country in 2017-2018 [1]. Traditionally, Switzerland is leading the chart. And the top 10 most competitive countries are the USA, Singapore, the Netherlands, Germany, Hong Kong, Sweden, the United Kingdom, Japan and Finland Ukraine keeps losing its position in the chart, and in 2017 it took the 81 st place among 137 countries, going up by 4 positions comparing to 2016. According to the Global Competitiveness Report 2013-2014, Ukraine held the 84th place among 148 world countries, losing 11 positions in the chart comparing to the previous year. The closest neighbours of Ukraine that year were Uruguay and Tunisia. The leading positions were held by Switzerland, Singapore and Finland, which are the top three leaders. All the postSoviet countries have left Ukraine behind in the Global Competitiveness Index, except for Moldova that holds the 89th place (Table 1) [1]

Table 1: Positions of Ukraine and Other Countries in the Global Competitiveness Index

\begin{tabular}{|l|c|c|c|c|c|}
\hline $\begin{array}{l}\text { Positions of Ukraine and } \\
\text { other Countries in the Global } \\
\text { Competitiveness Index }\end{array}$ & 2013 & 2014 & 2015 & 2016 & 2017 \\
\hline Ukraine & 84 & 76 & 79 & 85 & 81 \\
\hline Georgia & 72 & 69 & 66 & 59 & 67 \\
\hline Turkey & 44 & 45 & 51 & 55 & 53 \\
\hline Russia & 64 & 53 & 45 & 43 & 38 \\
\hline Poland & 42 & 43 & 41 & 36 & 39 \\
\hline
\end{tabular}

According to the Global Competitiveness Report 2012-2013 and 2013-2014 presented by the World Economic Forum, Ukraine had reached the second stage of development, country with the efficiency-driven economy. Per capita GDP for those years was $\$ 362$ and \$3877 accordingly. In 2008-2009, Ukraine was already acknowledged by the World Economic Forum as a country with efficiency-driven economy, but after the big GDP decline in 2010-2011, Ukraine was assessed again as a country at a transition stage between the resource-based and efficiency-driven economy [1].

In 2013-2014 the Ukrainian position was worsened due to the political crisis and Russia's military aggression. Therefore, according to international assessments, Ukraine now is not considered as an investment-attractive country. Ukraine's drop in economical rankings is the main reason why during the several next years the country lost its investment attractiveness and, as a result, the foreign investments. According to the 2016 ranking, Ukraine dropped to the 85th position out of 140. And in 2015 Ukraine descended from the 76th to the 79th place. In 2016 Ukraine is standing near African Namibia and bankrupt Greece. Poland keeps the 36th place. Azerbaijan -is the 37th, and Russia holds the 43rd position.

The main reasons why Ukraine is losing its place in the ranking, which is one of the most important indices for the country growth, are the war conflict, political instability, the high level of corruption, the high rate of inflation, non-availability of cheap and longterm credit lines, the high crime rate, and the poor health of the population. And the biggest impact on this situation was made by macroeconomic indices of Ukraine - they put the Ukraine to the 12th place from the end in a separate column of this ranking.

To sum up, all the mentioned factors still influence the Ukrainian opportunity to attract foreign capital. For example, now Ukraine is still trying to get back to the economic development figures which it had already had before the Eastern conflict. But if truth be told, Ukraine has some positive dynamics now.

In the Global Competitiveness Index 2017-2018 prepared by the experts of the World Economic Forum, Ukraine took the 87th place by the 'Transport Infrastructure' indicator, having moved up 10 positions in the ranking as compared to the previous period (Table 2) [1].

Table 2: Transport Infrastructure of Ukraine by GlobalCompetitiveness Index

\begin{tabular}{|l|c|c|c|c|}
\hline \multirow{2}{*}{ Indicator } & \multicolumn{4}{|c|}{ Place hold by Ukraine } \\
\cline { 2 - 5 } & $\begin{array}{c}2014- \\
2015\end{array}$ & $\begin{array}{c}2015- \\
2016\end{array}$ & $\begin{array}{c}2016- \\
2017\end{array}$ & $\begin{array}{c}2017- \\
2018\end{array}$ \\
\hline Transport infrastructure, incl. & 88 & 91 & 91 & 87 \\
\hline Quality of roads & 139 & 132 & 134 & 130 \\
\hline $\begin{array}{l}\text { Quality of railroad infrastruc- } \\
\text { ture }\end{array}$ & 25 & 28 & 34 & 37 \\
\hline Quality of port infrastructure & 107 & 108 & 96 & 93 \\
\hline
\end{tabular}

As we can see, the quality of Ukrainian railroad infrastructure is up to par, especially as related to other modes of transport, in view of the fact that the ranking covered 148 countries. This indicates the high investment attractiveness of the rail transport as compared to other modes of transport. In addition, investments in the transport infrastructure have a significant economic and social impact. Thus, one invested dollar gives 2-3 dollars of nominal GDP growth, and the creation of a job in the transport sector results in the creation of 6 jobs in other sectors.

\subsection{Definitions of the Concept of Investment Attractive- ness. Systematization of the Definitions}

Nowadays, the concept of investment attractiveness remains a reason for scholarly discussions. Thus far, no holistic view has been given for the content of the investment attractiveness concept in the economic literature.

For example, in the opinion of G. Birman and S. Schmidt, investment attractiveness is a combination of indicators that characterize the financial position of an enterprise [2].

Other scholars, such as M.N. Kreinina and S.P. Kontorovich, considered that investment attractiveness should be understood to mean the system of fundamental and equity market indicators in relation to the investment project in the first case, and the system of formal and informal indicators in the second case [3]. Moreover, formal indicators are calculated on the basis of financial reporting data, while informal ones do not have a certain set of output data, and thus are evaluated by expertise.

Based on the study of the existing views on the definition of the concept of investment attractiveness in literary sources, these views have been grouped by the main essential feature used for the definitions (Table 3). Such essential features as efficiency, opportunity for investors, a combination of factors, and a comparative indicator have already been marked [4].

However, in our opinion, another more essential feature must be added, more specifically, the interpretation of investment attractiveness as an integrated indicator (Table 3). 
Table 3: The Concept of Investment Attractiveness. Systematization of the Definitions

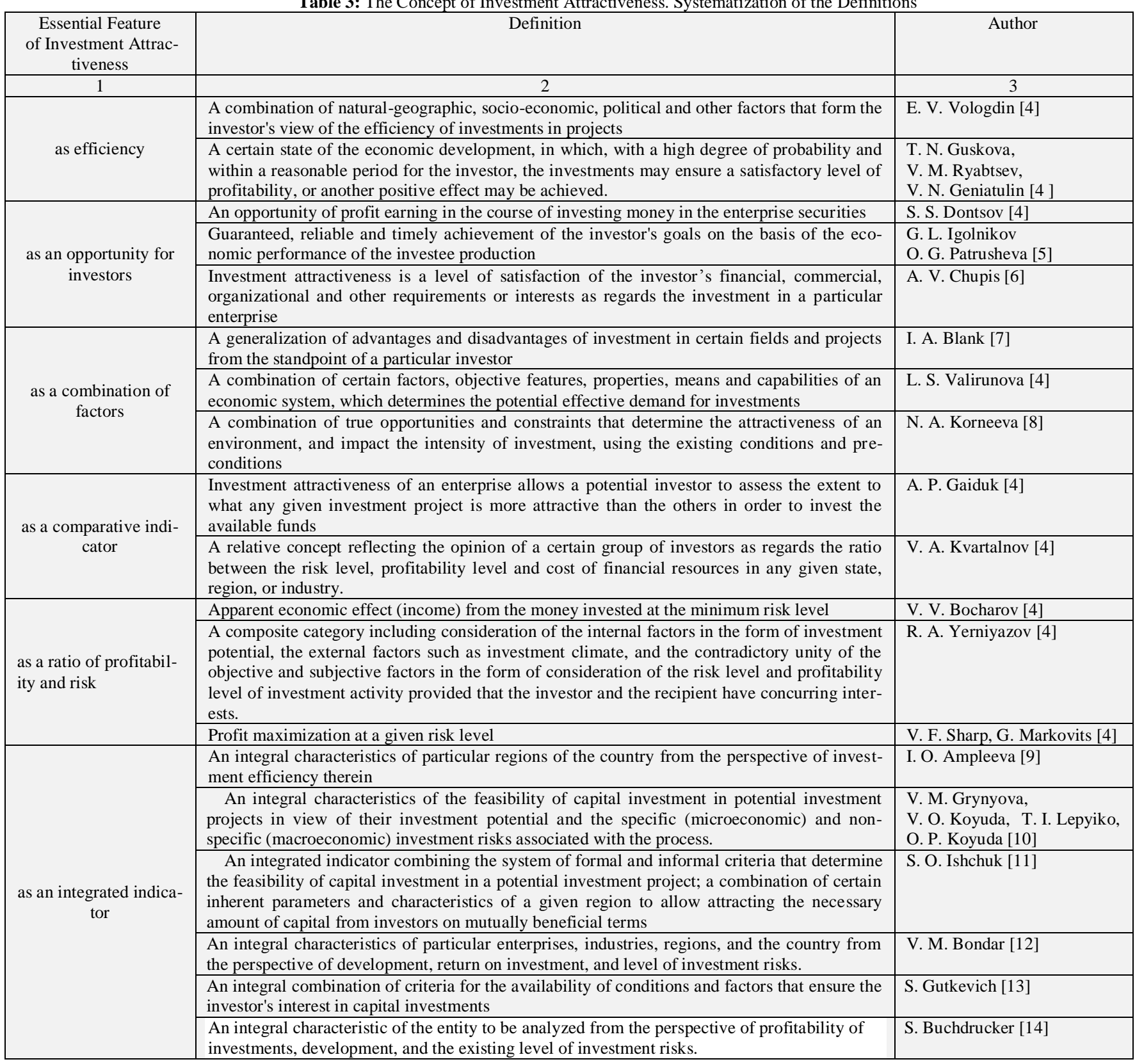

In our opinion, the definitions of investment attractiveness by V.M. Bondar and S. Buchdrucker are more preferable than the others in terms of qualimetry, since they include quantitative characteristics (profitability of investments) and qualitative ones (level of investment risks).

\subsection{Investments in Rail Transport}

The connectivity of the transport system has always been one of the crucial factors for forming the investment climate and investment attractiveness of a country or a region. The rail transport is the mode of transport in a common transport system, which, along with some disadvantages, has significant advantages, since it does not depend on weather conditions and is rightly considered to be the safest.

The quality of any transport at the service market depends, first of all, on the technical level of the transportation service. This level shall be assessed by certain quantitative and qualitative indicators. The latter directly affect the qualitative indicators of the transportation services, such as coherence, regularity, safety, security, and environmental safety.
Efficient and sustainable development of rail transport, adoption of high technologies, and integration of the Ukrainian national transport network into the global network are impossible without promotion of investments, and attraction of potential investors in the railroad industry. Signing of the Association Agreement between Ukraine and the EU has created new strategic prospects, and at the same time has intensified the need for significant investments to integrate the national transport system into the TransEuropean one.

The implementation of the Transport Strategy for the period until 2020 will enable creating favourable conditions to ensure the investment attractiveness of the transport industry, and the development of public-private partnerships. It will also enable attracting investors to improve the health of the transport infrastructure of Ukraine [15].

Possible areas for investments reflect the diversity of forms, methods and participants of the investment process. The special aspects of investments in rail transport in different countries are presented in Table 4 . 
Table 4: Special Aspects of Investments in Rail Transport

\begin{tabular}{|c|c|}
\hline Country & $\begin{array}{l}\text { Special aspects, Prospects, and } \\
\text { Some Results }\end{array}$ \\
\hline Great Britain & $\begin{array}{l}\text { Investments in the digital railway, transforming the } \\
\text { railways with digital innovation. } \\
\text { It results in an increased rail capacity, reduced trans- } \\
\text { portation costs, real-time monitoring of the rolling } \\
\text { stock and infrastructure, improved customer aware- } \\
\text { ness, and coherence with other modes of transport } \\
\text { [16]. }\end{array}$ \\
\hline Azerbaijan & $\begin{array}{l}\text { It is planned to bring the volume of investments in the } \\
\text { railway system up to } \$ 2 \text { billion by } 2020 \text {. Within the } \\
\text { framework of the investment projects aimed at im- } \\
\text { proving the railroad facilities, the electric power sup- } \\
\text { ply system shall be converted to AC, the Astara- } \\
\text { Astara railway shall be constructed, a thousand rail } \\
\text { cars and many containers shall be purchased [17]. }\end{array}$ \\
\hline France & $\begin{array}{l}\text { The aggregate investments is } € 13 \text { billion. Financing } \\
\text { through public and private partnership [18]. }\end{array}$ \\
\hline Australia & $\begin{array}{l}\text { Investing within 3-4 years; implementation of more } \\
\text { than } 100 \text { major capital projects [19]. }\end{array}$ \\
\hline China & $\begin{array}{l}\text { Investing all over the world. Growth of foreign direct } \\
\text { investments. Need for investments in infrastructure. } \\
\text { Investments in the digital railway, taking into account } \\
\text { China's plans to implement the concepts of the Silk } \\
\text { Road Economic Belt and the } 21 \text { st Century Maritime } \\
\text { Silk Road [20]. }\end{array}$ \\
\hline Poland & $\begin{array}{l}\text { The aggregate investments amounted to } € 4 \text { billion. A } \\
\text { part of the investments is aimed at the repair and } \\
\text { modernization of the railway routes. } \\
\text { Results: an increased capacity of Polish railroads, an } \\
\text { increased speed of trains [21]. }\end{array}$ \\
\hline $\begin{array}{l}\text { Serbia and } \\
\text { Bulgaria }\end{array}$ & $\begin{array}{l}\text { The amount of investments is } € 268 \text { million. Direc- } \\
\text { tions for investments: modernization of the railroad } \\
\text { bed; electrification; installation of new signalling } \\
\text { systems [22]. }\end{array}$ \\
\hline Russia & $\begin{array}{l}\text { The investments amount to RUB } 12.5 \text { trillion (con- } \\
\text { servative scenario) or RUB } 18.7 \text { trillion (innovation } \\
\text { scenario) for the implementation of the Russian Rail } \\
\text { Transport Development Strategy till } 2030 \text {. The } \\
\text { sources of financing are budget funds and private } \\
\text { investors [23]. }\end{array}$ \\
\hline
\end{tabular}

Based on the research conducted, it is possible to determine the following main directions for investments in rail transport in Europe and South-East Asia:

- purchase of the rail cars and containers;

- investments in the digital railways; and

- repair and modernization of the routes.

The investment attractiveness of railways is associated, first of all, with the conservatism of the railroad industry, which manifests itself in stability at relatively low risks. In addition, any process goes on relatively slow, so the investments are more secure as compared to the investments in other industries.

Secondly, the said attractiveness is associated with energy efficiency. From the standpoint of the International Electrotechnical Commission (IEC), it was stated that the rail transport is the most energy efficient of all modes of transport, and this energy efficiency can be further improved [24].

In the third place stands the possibility of innovations. An example is digital railway, one of the specific projects of digital economy [25].

The fourth, it's the safety of transportation. The rail transport is the mode of transport in a common transport system, which, along with some disadvantages, has significant advantages - apart from the fact that it does not depend on weather conditions, it is rightly considered to be the safest. At the present stage, the integration processes are governed by international standards including the safety requirements. The European Train Control System (ETCS) is designed to eliminate discrepancies in the incompatible signalling and interlocking systems of the European countries, which results in faster and safer rail traffic across the European continent) [26]. Since 2004, introducing the ETCS is mandatory for all the new and reconstructed Trans-European rail corridors of the European Union. Besides, implementing these standards involves innovation in the international rail industry [27].
Priority directions for investments in rail transport in Ukraine are as follows:

- building of a network of the interconnected logistics centres and multimodal terminals at the largest transport hubs and inspection posts at the state border of Ukraine and EU member countries;

- designing, financing, renovation and operation in construction of the new and rehabilitation of the existing railway tracks, stations, pedestrian bridges and tunnels, passenger platforms and other rail transport facilities related to passenger service under public-private partnership;

- construction of high-speed rail corridors to increase the economic efficiency of passenger transportation; and

- purchase of freight wagons, and operation of the freight rolling stock [15].

\section{Results and Conclusion}

We will determine the investment attractiveness from the qualimetric point of view. It may be expressed by the additive formula:

$I=I_{1}+I_{2}$

where $\boldsymbol{I}_{1}$ is the summand that depends on the quantitative characteristics

and $\boldsymbol{I}_{2}$ is the summand that depends on the qualitative characteristics.

Each of the summands, $\boldsymbol{I}_{1}$ and $\boldsymbol{I}_{2}$. depend both on the exter-

nal factors (the investment climate) and internal factors that characterize the enterprise itself. It follows that each of the summands in formula (1) can be represented as the sum of two summands, i.e.

$I=I_{11}+I_{12}+I_{21}+I_{22}$

where $I_{11}$ is the summand that depends on the external quantitative characteristics,

$I_{12}$ is the summand that depends on the internal quantitative characteristics,

$I_{21}$ is the summand that depends on the external qualitative characteristics,

$I_{22}$ is the summand that depends on the internal qualitative characteristics.

The summands $I_{11}$ and $I_{12}$ depend on the quantitative characteristics. This relationship can be determined by expert, statistical or analytical methods and expressed as functions $F\left(I_{11}\right)$ and $F\left(I_{12}\right)$. The functions $F\left(I_{11}\right)$ and $F\left(I_{12}\right)$, obviously, depend on the vector of quantitative characteristics.

The summands $I_{21}$ and $I_{22}$ depend on the qualitative characteristics. Some of these characteristics, such as the average numerical characteristics, can be measured numerically in a natural way. The other part is defined linguistically. This part should be transformed into numerical relations by methods of qualimetry. In this way, we can write each of the summands, $I_{21}$ and $I_{22}$, as a form with undetermined coefficients. We can define the undetermined coefficients of these forms by standard methods. This algorithm also allows us to express the summands $I_{21}$ and $I_{22}$ in the form of functions that depend on the vector of qualitative characteristics, $F\left(I_{21}\right)$ and $F\left(I_{22}\right)$.

Thus, formula (2) is transformed to the form:

$I=F\left(I_{11}\right)+F\left(I_{12}\right)+F\left(I_{21}\right)+F\left(I_{22}\right)$ 
The functions constructed above can be functions of either one or several variables. The right side of the sum (3) can be considered as a complex assessment of investment attractiveness.

When evaluating (calculating) investment attractiveness, one should distinguish between the concepts "level of economic development" and "investment attractiveness". The first concept determines the level of development of an object (a set of economic indicators) and characterizes the state of the object at the considered moment. The second one characterizes the state of the object, its further development, the prospect of profitability and growth in the future. Therefore, the investment attractiveness of an entity should be considered in dynamics, as a function of time. It should be noted that "the level of economic development" determines the investment attractiveness as a function at the initial moment of time.

To study the investment attractiveness as a function of time, it is necessary to go from the equation (3) to the differential equation.

Let for time $\Delta \mathrm{t}$ investment attractiveness $I$ and the summands $F\left(I_{11}\right), F\left(I_{12}\right), F\left(I_{21}\right), F\left(I_{22}\right)$ change accordingly to $\Delta I$ and $\Delta F\left(I_{11}\right), \Delta F\left(I_{12}\right), \Delta F\left(I_{21}\right), \Delta F\left(I_{22}\right) \cdot$

Then it follows from equation (3) that

$$
\Delta I=\Delta F\left(I_{11}\right)+\Delta F\left(I_{12}\right)+\Delta F\left(I_{21}\right)+\Delta F\left(I_{22}\right)
$$

We divide both sides of the equation by $\Delta \mathrm{t}$ and pass to the limit for $\Delta t \rightarrow 0$, and we have:

$$
\frac{\partial I}{\partial t}=\frac{\partial}{\partial t} F\left(I_{11}\right)+\frac{\partial}{\partial t} F\left(I_{12}\right)+\frac{\partial}{\partial t} F\left(I_{21}\right)+\frac{\partial}{\partial t} F\left(I_{22}\right)
$$

Let $t_{1}$ be the duration of the proposed investment. We integrate both sides of equation (5) from $\mathrm{t}=0$ to $t=\mathrm{t}_{1}$. We have:

$$
\int_{0}^{\mathrm{t}_{1}} \frac{\partial I}{\partial t} d t=\int_{0}^{\mathrm{t}_{1}}\left(\frac{\partial}{\partial t} F\left(I_{11}\right)+\frac{\partial}{\partial t} F\left(I_{12}\right)+\frac{\partial}{\partial t} F\left(I_{21}\right)+\frac{\partial}{\partial t} F\left(I_{22}\right)\right) d t
$$

We calculate the integral in the left-hand side of equation (6), and have:

$$
I\left(\mathrm{t}_{1}\right)=\int_{0}^{\mathrm{t}_{1}}\left(\frac{\partial}{\partial t} F\left(I_{11}\right)+\frac{\partial}{\partial t} F\left(I_{12}\right)+\frac{\partial}{\partial t} F\left(I_{21}\right)+\frac{\partial}{\partial t} F\left(I_{22}\right)\right) d t+I(0)
$$

where $I\left(\mathrm{t}_{1}\right)$ is the investment attractiveness of a railroad entity for investments of duration $\mathrm{t}_{1}$, and $I(0)$ is the level of economic development of the entity.

Equation (7) is a mathematical model of the qualitative evaluation of entity's investment attractiveness.

The variable $I\left(\mathrm{t}_{1}\right)$ is a numerical (dependent) variable. We can assign the value of a linguistic variable, the investment attractiveness (high, medium, or low) of the entity, to the value $I\left(\mathrm{t}_{1}\right)$

Thus, the developed qualimetric model enables the most adequate and essential assessment of the investment attractiveness of a railroad entity, based on the external and internal factors, and both qualitative and quantitative characteristics.

\section{References}

[1] The Global Competitiveness Index. https://www.weforum.org/reports/the-global-competitivenessreport-(2017-2018)

[2] Birman G., Shmidt S, Investments: Economic analysis of investment projects, M. YuNITI-DANA, (2003), 631.
[3] Kreynina M.N., Analysis of financial status and investment attractiveness of joint-stock companies in industry, construction and trade, M. Delo i servis, (1994).

[4] Cubera K.V., The essence of the investment attractiveness of the enterprise as an economic category // Development management, (2014), vol. 10, pp. 112-114.

[5] Igolnikov G.L., Patrusheva Ye.G., Management bases of innovativeinvestment activity of industrial enterprises - Yaroslavl : Yarosl state university, (2002), 107.

[6] Chupis A.V., Investing in the agrarian secto, Sumy: Environment, (2002), 244

[7] Blank I.A., Fundamentals of Investment Management, M: OMYeGA-L., (2008), 448.

[8] Kornjejeva N.A., Methodical approaches to building a comprehensive integrated assessment of investment attractiveness at the regional level // Actual problems of the economy, (2007), Vol. 2, pp. 106-111.

[9] Ampljejeva I.O., Regional distribution of fixed capital investment // Scientific and Technical Information, (2005), Vol. 3(25), pp. 11-14.

[10] Gryniova V.M., Kojuda V.O., Lepejko T.I., Kojuda O.P., .Investment, Znannja, (2008), 452.

[11] Ishchuk S.O., Models of integral evaluation of the results of financial and economic activity of industrial enterprises of the region// Regional economy, (2008), Vol. 2, pp. 25-34.

[12] Bondar V.N., Counteraction of corruption at the municipal level // M. Volters Kluver, (2008), 272

[13] Gutkevich S., Formation of investment attractiveness of the agrarian sector of economy: diss. doc. econ Sciences: special 08.07.02 "Economy of agriculture"//National Science Center,( 2004), 384.

[14] Bukhdruker S., Investment attractiveness of the company: http:// www.cfin.ru.

[15] https:/mtu.gov.ua/content/investor.html

[16] Kupriyanovskiy V.P., Sinyagov S.A., Dobrynin A.P., BIM - Digital economy. How did you succeed? Practical Approach to the Theoretical Concept. part 1. BIM approaches and main benefits // International Journal of Open Information Technologies, (2016), T. 4 , Vol. 3. - pp.1-8.

[17] Investments in Azerbaijan's railways will reach five billion dollars http://azunion.org/ru/investicii-v-zheleznuyu-doroguazerbajdzhana-dostignut-pyati-milliardov-dollarov/

[18] Russian railways. Innovation of the railways of France // Railways of the World, (2014), Vol. 2, pp.18-20.

[19] Russian railways. Suburban and city rail connections in Sydney // Railways of the World, (2013), Vol. 2, pp.23-25.

[20] The Silk Road of the 21st Century. World expansion of Chinese investors. XXI century: from 2015 Ernst end Yang SNG B.V. http://tpp74.ru/storage/Pril\%20k\%20bul\%2043.pdf

[21] The cost of investments in Polish railway transport is 4 billion euros: http://www.radiopolsha.pl/6/42/Tematy/10320

[22] Serbia and Bulgaria upgrade the railways with the help of the European Investment Bank's dollars, https://traffic.od.ua/news/worldtrans/1200166\%20 Energy_Keep_the_power_on.pdf Retrieved: Jul, 2016.

[23] On the railway transport to 2030, you may need 12.5-18.7 trillion rubles:https://www.vedomosti.ru/business/articles 2014/11/06/zheleznodorozhnye-ambicii

[24] Electrical energy the IEC helps keep the power on. IEC 2013g.:http://www.iec.ch/about/brochures/pdf/technology/IEC_Ele ctrical\%2 0Energy_Keep_the_power_on.pdf Retrieved: Jul,2016.

[25] Kupriyanovskiy V P, Sinyagov S A, Dobrynin A P BIM Digital economy. How did you succeed? Practical Approach to the Theoretical Concept. part 2. Digital economy //International Journal of Open Information Technologies, (2016), T. 4,Vol, 3, pp.9-20.

[26] Directive 2004/50/EC of the European Parliament and the Council Brussels: European Parliament and the Council, 2004.

[27] Future of Rail 2050. ARUP 2015 https://www.arup.com/publications/research/section/future-of-rail2050 